\title{
FOLLICULAR DEVELOPMENT IN HEIFERS INFUSED WITH FOLLICLE-STIMULATING HORMONE*
}

\author{
D. B. LASTER $\uparrow$ \\ Department of Animal Science, Iowa State University, Ames, Iowa 50010, U.S.A.
}

(Received 30th fuly 1971, accepted 20th September 1971)

Follicle-stimulating hormone from different species has been used to increase ovulation and calving rates in cattle, injections proving to be most successful when given during the late follicular phase of the oestrous cycle or in combination with progestagens (Willett \& Buckner, 1953; Bellows, Anderson \& Short 1969). Some investigations have resulted in substantial increases in ovulation and calving rates, but there is usually a high degree of variation in ovarian response. Patterns of follicular growth and atresia have been studied in cattle (Rajakoski, 1960) and hypotheses have been suggested to explain how exogenous FSH stimulates follicle growth in relation to normal stages of growth and atresia (Schilling \& Holm, 1963).

There are no investigations on histometric evaluation of follicular development after FSH treatment. The purpose of this study was to determine follicular response after constant infusion of FSH from different species sources and to evaluate variation in follicular response among heifers when a constant level of exogenous FSH is maintained in the systemic circulation during late pro-oestrous.

Twenty-one yearling Holstein heifers, ranging in weight from 236 to $454 \mathrm{~kg}$, were used. They were checked twice daily for oestrus with vasectomized bulls. All heifers were observed in standing oestrus at least three consecutive oestrous periods before random assignment to the treatment groups. The heifers were infused with a bovine (LER-1306-2), ovine (NIH-FSH-s8) or porcine (Armour FSH-P, Lot No. 14302) FSH preparation. The preparations, in a saline medium, were infused into the jugular vein at the rate of $0.382 \mathrm{ml} / \mathrm{min}$ for $72 \mathrm{hr}$. The heifers were restrained in a chute and the hormones were administered by a constant infusion pump.

Total dosages of the bovine and ovine FSH were equivalent to $9.75 \mathrm{mg}$ NIH-FSH-s1. Total dosages of the porcine FSH were $5.0,7.5$ or 10.0 mg equiv., but biological assay of FSH activity by the HGG augmentation method (Steelman \& Pohley, 1953) revealed that these levels were equivalent to $1.82,2.74$ and $3.65 \mathrm{mg}$ NIH-FSH-s1. Infusion of FSH in these heifers was initiated 3 days before the expected day of oestrus.

In three heifers, ovarian activity was suppressed by feeding $180 \mathrm{mg} 6$ methyl-17-actoxyprogesterone (MAP)/day for 12 days. Corpus luteum regression was induced by an intramuscular injection of $5 \mathrm{mg}$ oestradiol valerate

* Journal Paper No. J-6987 of the Iowa Agriculture and Home Economics Experiment Station, Ames, Iowa. Project No. 1325.

† Present address: U.S. Meat Animal Research Center, USDA, Clay Center, Nebraska 68933. 
on Day 2 of MAP feeding (Wiltbank \& Kasson, 1968). These heifers were infused with $2.74 \mathrm{mg}$ porcine FSH (NIH-FSH-sl equiv.) during the last 3 days of the MAP feeding period.

All heifers given FSH were bilaterally ovariectomized through a paralumbar incision $15 \mathrm{hr}$ after the end of the infusion period. For controls, three heifers were ovariectomized on the expected day of oestrus.

The ovaries were weighed, sliced in two sections, fixed in Bouin's fluid and embedded with celloidin. All ovaries were serially sectioned at $20 \mu \mathrm{m}$ and every twentieth section was mounted and stained with haematoxylin and eosin. Every one-hundredth section was stained with Mallory's triple stain. Histometric measurement was made of follicles with a diameter $\geqslant 2 \mathrm{~mm}$. An ovulation point, verified histologically, was considered as a normal 18-mm follicle for statistical analyses. Follicles $\geqslant 10 \mathrm{~mm}$ diameter were evaluated for atresia as described by Rajakoski (1960) and Marion, Gier \& Choudary (1968). Corpora lutea from the preceding ovulation were classified and given a numerical score on the basis of the number of lutein secretory cells as functional (1), partially regressed (2) or regressed (3).

Luteinizing hormone potency was 0.013 NIH-LH-sl units/mg for the NIH-FSH-s8 preparation (Endocrinology Study Section, NIH) and 0.003 NIH-LH-s1 units/mg for the LER-1306-2 bovine FsH preparation (Leo E. Reichert, Jr, personal communication). Contamination with LH in the Armour porcine FSH was 0.31 NIH-LH-sl units/mg equiv. FSH as determined by the ventral-prostate response in hypophysectomized rats (Greep, Van Dyke \& Chow, 1941).

The data on the diameter of follicles of both ovaries were combined and analysed by analysis of variance. Duncan's Multiple Range Test was used to compare differences among group means (Steel \& Torrie, 1960). Because there was heterogeneity of subgroup variances, the number of follicles $\geqslant 5 \mathrm{~mm}$ and $\geqslant 10 \mathrm{~mm}$ diameter were transformed to logarithms for statistical analyses (Winer, 1962).

Follicular response to the FSH treatments are shown in Table 1. All treated groups had a greater $(P<0.05)$ number of follicles $\geqslant 5 \mathrm{~mm}$ and $\geqslant 10 \mathrm{~mm}$ in diameter than did the control group. Increasing the levels of the porcine Armour FSH preparation increased $(P<0.05)$ the number of follicles $\geqslant 10 \mathrm{~mm}$ diameter. Heifers given ovine FsH had a greater $(P<0 \cdot 05)$ number of follicles $\geqslant 10 \mathrm{~mm}$ in diameter than those given a comparable level of bovine FsH. Although the FsH potency of the bovine preparation was 3.5 times greater than the $2.74 \mathrm{mg}$ porcine FsH, there was no difference in the mean number of follicles $\geqslant 10 \mathrm{~mm}$ in diameter. In addition, $3.65 \mathrm{mg}$ porcine FsH stimulated more $(P<0.05)$ follicular development than $9.75 \mathrm{mg}$ bovine FSH.

There were no differences in follicular response between heifers given 2.74 mg porcine FsH during the last 3 days of MAP feeding and those infused with the same level of gonadotrophin during the last 3 days before the expected day of oestrus. Suppression of ovarian activity with MAP combined with FSH treatment, however, decreased the variation in the mean number of follicles $\geqslant 10 \mathrm{~mm}$ diameter.

The presence of a functional or partially functional corpus luteum at the time of FSH treatment decreased $(P<0.01)$ follicular response. The corpora 


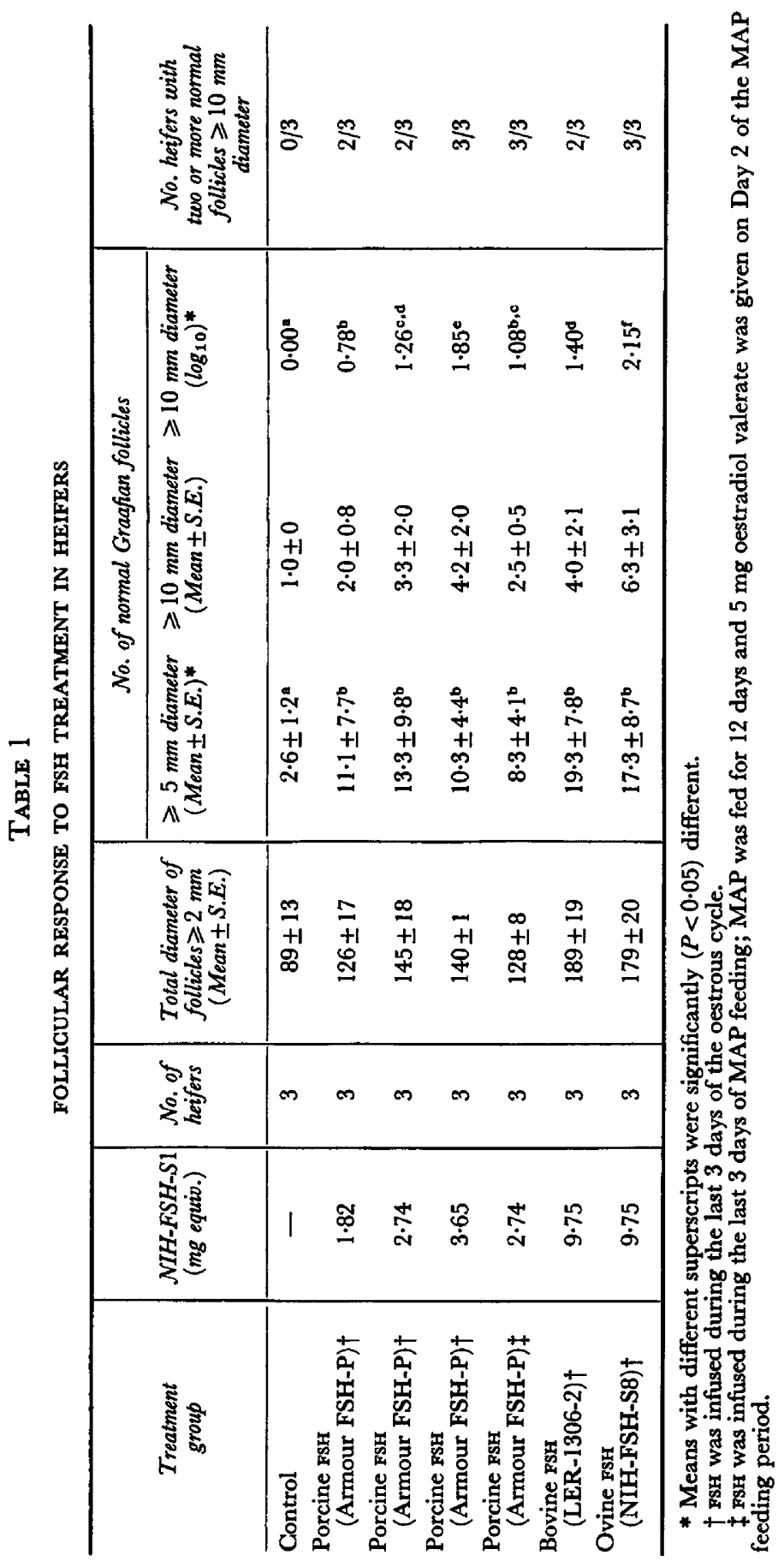


lutea scores (mean \pm S.E.) for the heifers with one, two to three, or more than three follicles $\geqslant 10 \mathrm{~mm}$ diameter were $1.33 \pm 0 \cdot 47,2 \cdot 25 \pm 0.82$ and $3 \pm 0.0$, respectively.

Follicles of 2 to $4 \mathrm{~mm}$ diameter responsed to the FSH preparations. Control and treated heifers had approximately the same total number of Graafian follicles $\geqslant 2 \mathrm{~mm}$ diameter, but the controls had more follicles of 2 to $4 \mathrm{~mm}$ diameter and fewer $\geqslant 5 \mathrm{~mm}$ diameter than the treated groups. The mean number of follicles $\geqslant 2 \mathrm{~mm}(78 \pm 6)$ was relatively constant among all groups. Atresia in follicles $\geqslant 10 \mathrm{~mm}$ diameter was detected in only one control and one FsH-treated heifer.

The follicle destined to ovulate in a cycling cow is 10 to $12 \mathrm{~mm}$ diameter at the onset of oestrus (Rajakoski, 1960; Marion et al., 1968). Although it was not assumed that all follicles $\geqslant 10 \mathrm{~mm}$ diameter at the time of ovariectomy would have ovulated, the number of these follicles was one of the primary criteria for evaluating the response to the FSH treatments.

These results indicate that exogenous LH enhances the follicle-stimulating activity of FsH given to heifers during late pro-oestrus as well as during the suppression of ovarian activity with an oral progestagen and oestradiol valerate. This suggests that lower levels of FSH preparations, which contain substantial amounts of LH, will stimulate follicular growth to a degree which is comparable to that obtained with much higher levels of more purified rsH preparations. A high exogenous LH: FSH ratio, however, is not required for follicular stimulation in heifers treated with FSH. Both the bovine and ovine preparations, which contained negligible quantities of $\mathrm{LH}$, stimulated follicular development. Appreciable quantities of $\mathrm{LH}$ were present only in the porcine FSH preparation, but other workers have reported that FSH and LH act synergistically to stimulate follicular development (Hisaw, 1947) and ovulation (Labhsetwar, 1970). The ovine FSH stimulated a greater follicular response than the bovine preparation though one might have expected that the FSH of bovine origin would give a higher response since il was used in the same species.

Infusing a constant level of FSH into the systemic circulation during late pro-oestrus or during progestagen feeding did not decrease the variation in ovarian response as compared with studies in which FSH was injected intramuscularly twice daily for 5 days (Bellows et al., 1969). Treatment with FSH during the suppression of ovarian activity with MAP and oestradiol valerate and the relationship between the integrity of the corpus luteum and follicular response indicate that some of the variation of follicular response to exogenous FSH may be caused by variation in levels of endogenous gonadotrophins and progesterone.

Since atresia was detected in only two follicles $\geqslant 10 \mathrm{~mm}$ diameter, it seems that the levels of exogenous FSH used in this study were sufficient to stimulate and maintain stimulation of one or more large follicles. Early stages of atresia may not have been detected in some of these follicles, but few large atretic follicles are found during late pro-oestrus in the cycling cow (Rajakoski, 1960).

This work was supported by grants from HEW, NIH HD-01168-11 and HD-00184-04 and from the Iowa State University Research Foundation. 
Appreciation is expressed to Dr R. M. Melampy for his advice, Dr L. L. Anderson for his advice and assistance, Dr Leo E. Reichert, Jr, for the bovine FSH (LER-1306-2), Endocrinology Study Section, NIH, for the NIH-FSH-s8, and the Upjohn Company, Kalamazoo, Michigan for the MAP.

\section{REFERENCES}

Bellows, R. A., Anderson, D. C. \& Short, R. E. (1969) Dose-response relationships in synchronized beef heifers treated with follicle stimulating hormone. F. Anim. Sci. 28, 638.

Greep, R. O., VAn DyKe, H. B. \& Chow, B. F. (1941) Use of anterior lobe of prostate gland in the assay of metakentrin. Proc. Soc. exp. Biol. Med. 46, 644.

Hisaw, F. L. (1947) Development of the Graafian follicle and ovulation. Physiol. Rev. 27, 95.

LABHSETwAR, A. P. (1970) Synergism between LH and FSH in the induction of ovulation. $\mathcal{F}$. Reprod. Fert. 23, 517 .

Marion, G. B., Gier, H. T. \& Choudary, J. B. (1968) Micromorphology of the bovine ovarian follicular system. F. Anim. Sci. 27, 451.

Rajakoskr, E. (1960) The ovarian follicular system in sexually mature heifers with special reference to seasonal, cyclical, and left-right variations. Acta endocr., Copenh. Suppl. 52, 1.

Schilling, E. \& Holm, W. (1963) Investigation on induction of limited multiple ovulations in cattle. 7. Reprod. Fert. 5, 283.

Steel, R. G. D. \& Torrie, J. H. (1960) Principles and procedures of statistics. McGraw-Hill, New York.

Steelman, S. L. \& Pohley, F. M. (1953) Assay of the follicle stimulating hormone based on the augmentation with human chorionic gonadotropin. Endocrinology, 53, 604.

WiLlett, E. L. \& BuckNer, P. J. (1953) Refractoriness of cows repeatedly superovulated with gonadotropins. F. Dairy Sci. 36, 1083.

Wiltbank, J. N. \& KASSON, G. W. (1968) Synchronization of estrus in cattle with an oral progestational agent and an injection of an estrogen. F. Anim. Sci. 27, 113.

WINER, B. J. (1962) Statistical principles in experimental design. McGraw-Hill, New York. 